\title{
Analysis of the Level of Financial Literacy among South African Undergraduate Students
}

\author{
*Emmanuel K. Oseifuah, Agyapong B. Gyekye \\ University of Venda, South Africa \\ *oseifuah@univen.ac.za
}

\begin{abstract}
The purpose of the study was twofold: to examine the relationship between financial literacy and demographic and other socioeconomic factors of a sample of undergraduate students; and to evaluate how undergraduate students' financial knowledge correlate with their attitude and behavior towards personal finance issues. A structured questionnaire was used to collect data and logistic regression and Chi-Square statistical procedures were employed to analyse the data using the Statistical Package for Social Scientists (SPSS) software. Overall, this pilot study reveals that Bachelor of Commerce(Accounting) students at the University of Venda are not as financially literate as expected, confirming the findings of similar studies conducted on South African university students (Kotzè and Smidt, 2008). There is therefore the necessity to review the academic curriculum in the Bachelor of Commerce programme to include money management course. Furthermore, with more South African university students likely to depend on bank loans to finance their education, it is recommended that financial literacy be made a compulsory course in all undergraduate programmes in South African universities.
\end{abstract}

Keywords : Bachelor of Commerce, Financial Literacy, South Africa, Undergraduates, University of Venda

\section{Introduction}

Financial literacy is a crucial factor affecting individuals, households, financial institutions and the broader economy. Financial illiteracy has been cited by many commentators as a major reason for falling saving rates (Hilgert, Hogarth and Beverly, 2003), mounting consumer debt (Stango and Zinman, 2007), inadequate planning for retirement (Lusardi and Mitchell, 2006, 2007a), basis for divorce, poor mental health and a variety of other negative and unhappy experiences (Kinnunen and Pulkkinen, 1998; Cleek and Pearson, 1995), the cause of emotional stress, depression and lower self-esteem (Wolcott and Hughes, 1999). Researchers generally agree that financial knowledge appears to be directly correlated with self-beneficial financial behaviour (Hilgert, Hogarth, \& Beverly, 2003). For example, Perry and Morris (2005) found that financially literate individuals are more inclined to budget, save and plan for the future. Chang and Hanna (1992) reported that individuals with high levels of financial knowledge make more efficient decisions when compared with those possessing low levels of financial literacy. Finally, Kinsey and McAlister (1981) found a positive association between financial literacy and level of income and education. These indicators have prompted governments worldwide including Australia, Japan, Canada, US, and the UK to raise the level of financial literacy through purposive educational programmes. Recent researches have shown that financial literacy levels in developing countries are quite low. For example, DFID (2008) (cited in Njuguna, 2011) study reveals that only half of the adult population knew how to use financial products. The study also found that in 7 African countries about a third (29\%) of adults had a bank account and that approximately 50\% used no financial products whatsoever.

In South Africa, several financial literacy initiatives by government, private sector and Non-governmental organizations (e.g. Banking on our future (BOOF); Financial Services Board; VISA, Old Mutual, South African Insurance Association; and Life Officers Association, among others) have been implemented with the primary objective of educating and empowering the populace to become responsible and competent market consumers. However, empirical studies have revealed that the level of financial literacy is alarmingly low, especially among the adult population (FinMark Trust, 2004; Van Nieuwenhuyzen, 2009). For example, Godfrey (2006) found that nearly $60 \%$ of respondents do not understand the term 'interest'. Also, the South Africa Savings Institute (SASI, 2010) acknowledged in its Varsity Savings Campaign 2010 programme that many graduates go into the labour market with little understanding of how to manage their finances. Consequently, they squander their incomes as soon as they receive their first earnings on ostentatious goods and fall into debt due to failure to save or budget for their expenses. In addition, majority fail to save or budget for their money even though they intuitively know that this could improve their financial well-being. As a result, they tend to be unprepared and are ill-equipped to properly manage their salaries or realize the importance of making additional provision for their retirement during their working years. 
Worthy of note also is the recent financial literacy baseline study, which was undertaken by the Human Sciences Research Council, on behalf of the Financial Services Board (a first of its kind in South Africa). The findings revealed a strong evidence for the existence of low levels of financial knowledge among young people aged between 16 to 19 years. Specifically, the study found that majority of young people would prefer to spend money than to save it; that the majority of young people never enjoy dealing with financial matters and that young people are least likely to stay within their budgets. The study concludes with a recommendation of a more comprehensive and aggressive programme of consumer financial education in South Africa (Roberts, Struwig, Gordon, Viljoen, and Wentzel, 2012). Clearly, university students are potentially rewarding area for financial literacy research. The financial knowledge, attitudes and behaviours acquired during this period may affect their financial and economic wellbeing, both during their student years and in adulthood in profound ways. Non self-beneficial financial habits and attitudes and lack of financial knowledge can adversely impact on their academic performance, mental and physical well-being, and even their ability to find employment after graduation (Bodvarsson \& Walker, 2004; Lyons, 2003, 2004). On the other hand, positive financial behaviours and attitudes contribute to financial satisfaction, life satisfaction, academic performance and academic satisfaction amongst students. To quote an African wise saying, "it is easy to bend and direct the growth of a young supple tree". The purpose of this study was to investigate the level of financial literacy among South African undergraduate university students.

Objectives: The overall objective of the study was to assess the level of financial literacy among South African undergraduate students. The specific objectives were:

- To determine the level of financial knowledge among undergraduate students using standard financial literacy variables.

- To ascertain the relationship between financial literacy and both demographic and socioeconomic factors of a sample of undergraduate students.

- To evaluate how undergraduate students' financial knowledge correlate with their attitude and behavior towards personal finance issues.

Research Questions: This study seeks to answer the following research questions:

- What is the level of financially literacy among South African undergraduate students?

- Are there significant relationships between gender, age and socio-economic factors and financial knowledge (Literacy) among undergraduate students in South Africa?

- Are undergraduate students' financial knowledge correlated with their attitudes and behavior towards personal finance issues?

Hypotheses: The above questions were answered by testing the following hypotheses:

- $\quad$ South African undergraduate students are financially literate

- There is no significant relationship between gender and age in financial knowledge (Literacy)

- There is no significant relationship between socioeconomic status and financial knowledge.

- There is no significant correlation between attitudes and behavior towards personal finance issues and financial knowledge

\section{Methodology}

Study Sample and Data Collection: The study was conducted among students at the University of Venda in Thohoyandou, Limpopo Province of South Africa in July 2011. A structured questionnaire was constructed based on previous studies (see ANZ Survey of Adult Financial Literacy in Australia: Final Report, 2003; the Media Research Consultants Pte Ltd, 2005; Jorgensen, 2007; Chen and Volpe, 1998; Nieuwenhuyzen, 2009) to collect data for the study. The questionnaire contains questions on financial attitude, knowledge, behaviours, and influences, as well personal characteristics items. Due to time constraints, the questionnaire was administered only to final (third) year Bachelor of Commerce (Accounting) students. In all, 50 questionnaires were administered to students who volunteered to participate in the study. The participating students were classified into two groups using the median percentage of correct answers of the sample, on questions on financial knowledge. These questions included: What is net worth? Which account pays the most interest? ; What is the most important factor used by banks to decide on loan approval? ; What do credit bureaux do? ; What instrument is used to put money aside for emergencies? Students who scored higher than the sample median were regarded as those who are relatively more knowledgeable. Students who obtained scores equal to or below the 
sample median were classified as students who are relatively less knowledge. The data was analysed using the SPSS Statistical software and the results are presented and discussed below.

\section{Results}

This section reports the results of the data analysis. The presentation includes the demographic profile and other characteristics of the sampled students as well as the results of the statistical relationship based on Logistic regression and Chi-Square procedures performed in the context of the research questions

Description of Sample Characteristics: From the 50 questionnaires administered to the students, 45 were found to be usable and were therefore used in all subsequent analysis. Table 1 presents the characteristics of the sample used for the study. Forty four per cent of the participating students were males while 55\% were females. As expected, the majority of the participants (95\%) were below 30 years of age. More than $40 \%$ of participating students did not know how much income their parents earned last year. For the remaining participating students who had an idea about their parents' earning last year, the majority, 64\% , in the group opined that their parents earned less than R10 000 last year. This finding confirms the often held believe that majority of students at the University of Venda are from poor and disadvantaged households. As expected, most of the students (84\%) are South Africans. The participating students finance their university studies from variety of sources i.e. bank loans (40\%), parents $(30 \%)$, and bursary (28\%). Fifty per cent of the participants have fathers with secondary education, while $30 \%$ of fathers had university first degrees. With many students at the University of Venda coming from low income households, it is not surprising that for nearly 7 out of every 10 students in the sample (69\%) monthly pocket money is R500 or less. Missing responses made the sample size to vary from 36 to 45; therefore, various sample sizes have been used to calculate valid percentages in Table 1.

Table1: Characteristics of Sample ( $\mathrm{N}=45)$

\begin{tabular}{|c|c|c|c|}
\hline \multicolumn{2}{|l|}{ Characteristics } & \multirow{2}{*}{$\frac{\mathbf{n}}{25}$} & \multirow{2}{*}{$\frac{\%}{56}$} \\
\hline Gender & & & \\
\hline & & 20 & 44 \\
\hline \multirow[t]{4}{*}{ Age } & $18-22$ & 21 & 50 \\
\hline & $23-29$ & 19 & 45 \\
\hline & $30-35$ & 1 & 2 \\
\hline & $36-40$ & 1 & 2 \\
\hline \multirow[t]{3}{*}{ Year of Study } & $2^{\text {nd }}$ year & 1 & 2 \\
\hline & $3^{\text {rd }}$ year & 42 & 96 \\
\hline & $4^{\text {th }}$ year & 1 & 2 \\
\hline \multirow[t]{6}{*}{ Parents Annual income } & $\leq 10000$ & 17 & 38 \\
\hline & $10001-20000$ & 4 & 9 \\
\hline & $20001-30000$ & 1 & 2 \\
\hline & $30001-49999$ & 3 & 7 \\
\hline & $\geq 50000$ & 2 & 4 \\
\hline & Don't know & 18 & 40 \\
\hline \multirow[t]{4}{*}{ Level of Education father } & Primary & 6 & 17 \\
\hline & Secondary & 18 & 50 \\
\hline & Degree & 11 & 31 \\
\hline & Postgraduate & 1 & 3 \\
\hline \multirow[t]{4}{*}{ University Education Paid } & Self & 1 & 2 \\
\hline & Parents & 13 & 30 \\
\hline & Bursary & 12 & 28 \\
\hline & Other (Loans) & 17 & 40 \\
\hline \multirow[t]{2}{*}{ International Student } & Yes & 7 & 16 \\
\hline & No & 37 & 84 \\
\hline \multirow[t]{4}{*}{ Monthly Pocket Money } & $\leq \mathrm{R} 500$ & 29 & 69 \\
\hline & R5001-R1000 & 10 & 24 \\
\hline & R1001-R1500 & 2 & 5 \\
\hline & R1501-R2000 & 1 & 2 \\
\hline
\end{tabular}


Logistic Regression Results and Analysis: To analyse the relationship between student's level of financial literacy and his/her demographic and socioeconomic attributes, a Logistic regression model was estimated in which the binary variable (more knowledgeable and less knowledgeable) was used in the logistic regression as the dependent variable, which is explained by a number of independent variables. The independent variables used in the logistic regression included gender, age, nationality, parental income, education level of father, source of financial support, as well as monthly pocket income. In logistic regression, the coefficient of each independent variables represent the effect of each subgroup (of participating students) compared with a reference group. As an example, if GENDER is coded 1 if a participant is male and 0 otherwise. In this case the reference category is female. If the logistic coefficient is negative, it means that compared with female Accounting students, male Accounting students are associated with decreased log odds ratio of being more knowledgeable about personal finance.

The logistic model is expressed as follows:

$\log \left[\frac{p}{1-p}\right]=\beta 0+\beta 1($ GENDER $)+\beta 2($ AGE $)+\beta 3($ PINCOME $)+\beta 4($ EDU 1$)+\beta 5($ EDU 2$)+\beta 6($ EDU $)+$
$\beta 7($ SPONSOR 1$)+\beta 8($ SPONSOR 2$)+\beta 9($ SPONSOR 3$)+\beta 10($ NATIONALITY $)+\beta 11($ POCKETINC $)+\epsilon \mathrm{i}$

Where

$P \quad=$ the probability of a student who is more knowledgeable about personal finance

GENDER $\quad=1$ if participant is a male, 0 otherwise

AGE $\quad=1$ if participant is in the age group 18-22, 0 otherwise

PINCOME $\quad=1$ if participant knows parent's monthly income, 0 otherwise

EDU1 =1 if participant's father's highest education level is Primary, 0 otherwise

EDU2 =1 if participant's father's highest education level is Secondary, 0 otherwise

EDU3 =1 if participant's father's highest education level is Tertiary, 0 otherwise

SPONSOR1 =1 if university education is paid for by parents, 0 otherwise

SPONSOR2 =1 if university education is paid for by Bursary, 0 otherwise

SPONSOR3 =1 if university education is paid for by Bank Loans, 0 otherwise

NATIONALITY= 1 if participant is a foreign student, 0 otherwise

POCKETINC $=1$ if participant's monthly pocket money is $\leq \mathrm{R} 500,0$ otherwise

Results of the logistic regression are presented in Table 2. One measure that is widely used to show the goodness of fit of a model is how well the model is able to classify observations i.e. correctly predicts category membership into more knowledgeable and less knowledgeable. For the sample used in this study, $81.3 \%$ of the observations are correctly classified. In addition, the size and statistical significance of the Chi-Square value, confirms that the model has a high explanatory power. In other words, the independent variables are able to explain a substantive amount of variation in the dependent variable (i.e. financial literacy). Table 2: Logistic Regression Analysis of the Impact of Participants' Demographic Characteristics, Source of university education funding, father's level of education, and Monthly allowance on Their Financial Literacy

For the independent variables, the coefficient of GENDER is positive and significant at the 0.05 level of significance. The result suggests that male accounting students are more likely to be more knowledgeable about personal finance issues than their female counterparts. The highly significant positive coefficient for SPOSOR3 variable indicate students who pay for their university education through bank loans, are more likely to be more knowledgeable in personal finance matters than their counterparts financing their education through other sources such as bursaries or parents. The coefficient for POCKETINC is negative and significant at the 0.05 level, indicating that participating students with monthly pocket monies less than or equal to R500 are less likely to be financially knowledgeable compared to their counterpart with monthly pocket incomes of above R500. The variables AGE, PINCOME, EDU1, EDU2, EDU3 and NATIONALITY are individually not statistically significant at any of the conventional levels of 0.10 , or 0.05 or 0.01 . This implies that these variables do not affect the level of financial knowledge among the participating students. Knowing or not knowing their parents' monthly income (PINCOME), or the educational achievement of father (EDU) or whether foreign student or not appear not to account for any differences in financial knowledge among participating students. These are probably variables that would not be considered important in students' decision to know about personal finance issues. 


\begin{tabular}{lc}
\hline Estimated Coefficients and the Level of Significance for the sample of Participants \\
\hline GENDER & $0.458^{*}$ \\
AGE & 1.335 \\
PINCOME & 0.595 \\
EDU1 & 0.845 \\
EDU2 & 0.770 \\
EDU3 & 0.037 \\
SPONSOR1 & 2.880 \\
SPONSOR2 & 2.528 \\
SPONSOR3 & $3.550^{* *}$ \\
NATIONALITY & 1.324 \\
POCKETINC & $-2.592^{*}$ \\
CONSTANT & $2.142^{*}$ \\
-2 Log Likelihood & 281.37 \\
Overall Chi-Square & $15.093^{* *}$ \\
Correct Classification & $81.3 \%$ \\
Notes: $*$ Significant at the.05 level **Significant at the.01 level or greater \\
\hline
\end{tabular}

Chi-Square Results and Analysis: In this section we examine how a student's level of financial knowledge affects his/her attitude and behaviour towards personal finance. The same categorization of participants that was used to classify students as more knowledgeable and less knowledgeable for the logistic regression is employed in this section. Financial attitude among participating students was measured by their responses to a number of attributes of good financial attitude which were coded in a Likert-type scale. The attributes are maintenance of adequate financial records; spending less than one's monthly pocket money; and planning and implementing a savings plan. For each attribute, the respondent was asked to rate its importance by choosing among the scale 1=Not Important, 2-Not Sure, $3=$ Important, and 4=Very Important. Participants' responses to the importance of keeping financial records are presented in Table 3 About $81 \%$ of the participants from more knowledgeable group of students, rate maintaining adequate financial records as very important or important and the rest of them believe otherwise. For the less knowledgeable group, about 79\% view maintaining adequate financial records as very important or important. The Chi-Square statistic of the difference in opinion between the two groups is however not significant at any of the conventionally accepted levels of significance.

Table 3: Number and percentage of participants who view maintaining adequate financial records as:

\begin{tabular}{|c|c|c|c|c|c|}
\hline & $\begin{array}{l}\text { Very } \\
\text { Important }\end{array}$ & Important & $\begin{array}{l}\text { Not } \\
\text { Sure }\end{array}$ & $\begin{array}{l}\text { Not } \\
\text { Important }\end{array}$ & Total \\
\hline Students with more personal finance & 12 & 1 & 3 & 0 & 16 \\
\hline knowledge & $75 \%$ & 6.25 & $18.8 \%$ & $0.0 \%$ & $100 \%$ \\
\hline Students with less personal finance & 15 & 7 & 3 & & 28 \\
\hline knowledge & $53.6 \%$ & $25.0 \%$ & $10.7 \%$ & $10.7 \%$ & $100 \%$ \\
\hline
\end{tabular}

Chi-Square $=4.972$, level of significance is 0.177 , not significant at the 0.10 , or 0.05 or 0.01 level 
Table 4 indicates that $100 \%$ of the more knowledgeable participants rank spending less of their monthly pocket money more important than the less knowledge group (75\%).The Chi-Square test suggests that the differences in opinion is significant at the 0.061 level.

Table 4: Number and percentage of participants who view spending less of monthly income as:

\begin{tabular}{lllllll}
\hline & & $\begin{array}{l}\text { Very } \\
\text { Important }\end{array}$ & Important & $\begin{array}{l}\text { Not } \\
\text { Sure }\end{array}$ & $\begin{array}{l}\text { Not } \\
\text { Important }\end{array}$ & Total \\
\hline Students with more personal finance & 11 & 5 & 0 & 0 & 16 \\
knowledge & & $68.8 \%$ & $31.2 \%$ & $0.0 \%$ & $0.0 \%$ & $100 \%$ \\
Students with less & personal finance & 9 & 12 & 3 & 4 & 28 \\
knowledge & $32.1 \%$ & $42.9 \%$ & $10.7 \%$ & $14.3 \%$ & $100 \%$ \\
\hline
\end{tabular}

Chi-Square $=7.357$, significant at the 0.061 level

Table 5 shows that about $94 \%$ of the more knowledgeable group of student's view planning and implementing a regular savings/investment programme as important. For the less knowledgeable group, $75 \%$ regard planning and implementing regular savings/investment programme as important. The ChiSquare test however suggests that the difference in opinion between the two groups is not statistically significant at any of the conventionally accepted levels of significance, implying that more financially knowledgeable participants were not likely to implement a savings plan than their less knowledgeable colleagues. This may be due to the fact that these students depend on very meagre incomes. As indicated in Table 1, about $70 \%$ of all the participating students have monthly income of R500 or less. There is not much to save and therefore no need to make savings/investment plans.

Table 5: Number and percentage of participants who view Planning and implementing a regular savings/investment plan as:

\begin{tabular}{|c|c|c|c|c|c|}
\hline & $\begin{array}{l}\text { Very } \\
\text { Important }\end{array}$ & Important & $\begin{array}{l}\text { Not } \\
\text { Sure }\end{array}$ & $\begin{array}{l}\text { Not } \\
\text { Important }\end{array}$ & Total \\
\hline Students with more personal finance & 9 & 6 & 1 & 0 & 16 \\
\hline knowledge & $56.2 \%$ & $37.5 \%$ & $6.3 \%$ & $0.0 \%$ & $100 \%$ \\
\hline Students with less personal finance & 13 & 8 & 6 & 1 & 28 \\
\hline knowledge & $46.4 \%$ & $28.6 \%$ & $21.4 \%$ & $3.6 \%$ & $100 \%$ \\
\hline
\end{tabular}

Chi-Square $=2.497$, significant at 0.476 , not significant at the 0.10 or 0.05 or 0.01 level

This study also sought to establish the extent to which responding students who participate in family financial decisions as well as those who have formal training in money management or personal finance, are more financially knowledgeable than their less knowledgeable counterparts. Table 6 reports that about $56 \%$ of the more knowledgeable participating students do participate in family financial decision making, while only $28 \%$ of the less knowledgeable group take part in family financial decision making. The difference between the two groups, according to the Chi-Square test, is statistically significant at the 0.07 level of significance. Thus participants who had the experience of participating in family financial decisions were more likely to be financially knowledgeable. This finding is not unexpected as financially knowledgeable students possess the knowhow on financial issues and are thus able to properly advice and contribute to their families' decisions on financial matters.

Table 6: Number and percentage of participants who participate in family financial decisions

\begin{tabular}{lccc}
\hline \multicolumn{2}{c}{ Yes } & No & \multicolumn{2}{c}{ Total } \\
\hline Students with more personal & 9 & 7 & 16 \\
Finance Knowledge & $56.3 \%$ & 43.7 & $100.0 \%$ \\
& & & \\
Students with less personal & 7 & 18 & 25 \\
Finance Knowledge & $28.0 \%$ & $72.0 \%$ & $100.0 \%$ \\
\hline
\end{tabular}

Chi-Square $=3.272$, significant at the 0.07 level

In a similar vein to the relationship between financial knowledge and participation in family financial decision making, Table 7 indicates that $87.5 \%$ of the more knowledgeable participating students have taken a money management course compared to $56.5 \%$ of the less knowledgeable counterparts. The ChiSquare statistic is statistically significant at the 0.039 level suggesting that the difference between the groups is significant i.e. students who have taken a money management course is more likely to be financially knowledgeable. 
Table 7: Number and percentage of participants who have taken a money management course

\begin{tabular}{lccc}
\hline \multicolumn{2}{c}{ Yes } & No & \multicolumn{2}{c}{ Total } \\
\hline Students with more personal & 14 & 2 & 16 \\
Finance Knowledge & $87.5 \%$ & $12.5 \%$ & $100.0 \%$ \\
& & & \\
Students with less personal & 13 & 10 & 23 \\
Finance Knowledge & $56.5 \%$ & $43.5 \%$ & $100.0 \%$ \\
\hline
\end{tabular}

Chi-Square $=4.251$, significant at the 0.039 level

The above analysis suggests that attitudes towards financial record keeping and savings do not seem to differ significantly between financially literate students and the less literate ones. The study also found that students who participated in family financial decisions and those who have taken money management course are more likely to be financially literate.

Discussion: The first finding from the logistic regression indicates that male accounting students are more likely to be more knowledgeable about personal finance issues than their female counterparts. This finding appears to be consistent with the roles traditionally played by males and females in decision making in a typical African household where the male predominates in most decisions, including financial ones. Males are therefore more likely to want to learn more about financial issues than their female counterparts. This possible reason notwithstanding, with more and more women joining the labour market, together with the fact that they are expected to live longer than men; inadequate knowledge about personal finance among women has to be addressed. The second finding from the logistic regression is that students, who pay for their university education through bank loans, are more likely to be more knowledgeable in personal finance matters than their counterparts financing their education through other sources such as bursaries or parents. This is expected as such students are dependent on bank loans to satisfy their needs and as such they need to know about personal financial management issues including the need to maintain good credit payment record in order to be able to access further loans from banks; what a credit bureau does in connection with access to further credit; as well as the habit of saving for emergency needs.

Students with small monthly pocket monies were found to be less knowledgeable than their counterparts with larger monthly pocket monies. The plausible reason for this finding is that a pocket income of R500 or less is relatively small and is probably used for consumption purposes, and it is inadequate for such students to consider learning about various instruments for investing or saving. On the other hand the more fortunate students with larger pocket incomes, will be more disposed to know about various personal finance management matters such as how to save or invest part of the larger pocket monies and earn interest. Another interesting finding from the logistic regression is that the variable age does not affect the level of financial knowledge among the participating students. In respect of the AGE variable, Table 1 shows that $50 \%$ of the participants are $18-22$ years of age, and $95 \%$ of these students are under 30 . Thus the majority of them is in the early stage of their financial cycle, and therefore has to grapple with a very limited number of personal finance options. During this period, most of their incomes are spent on consumption rather than investment. These factors may explain the lack of difference in financial knowledge between participants between 18-22 years of age and participants who are above 22 years of age.

From the Chi-Square analysis, it was found that there is no significant association between one's willingness to keep financial records and their level of financial literacy. This finding implies that record keeping may not be necessary for individual to practice good personal finance. Another finding from the Chi-square analysis indicates that more knowledgeable participating students perceive spending less than their monthly income to be very vital than their less knowledgeable counterparts. Thus financial literates were more likely to be astute in their spending since they know the implications of doing otherwise. It was also found from the Chi-square analysis that more financially knowledgeable participating students were as unlikely to implement a savings plan as their less knowledgeable colleagues. This may be due to the fact that these students depend on very meagre incomes. As indicated in Table 1, about $70 \%$ of all the participating students have monthly income of R500 or less. There is not much to save and therefore no need to make savings/investment plans. A further finding from the ChiSquare analysis suggests that students who have taken a money management course are more likely to be financially knowledgeable. The finding is not surprising because a course in money management will contain a substantive dose on personal finance. Thus one of the main determinants of financial literacy is 
taking a course in financial management. The analysis also found that students who participated in family financial decisions and those who have taken money management course are more likely to be financially literate.

\section{Conclusion}

This study used a questionnaire instrument to survey a sample of 50 Accounting students at the University of Venda to assess the students' knowledge on personal finance; and the relationship between financial literacy and demographic (gender, age, nationality) and other factors such as source of financial support for their education, father's educational achievement, family incomes and monthly pocket money. The study further looked at the impact of financial knowledge on participating students' opinion on personal finance issues. The review of literature revealed that there has been extensive research on financial literacy among college/university students in other parts of the world; there have been very few such studies in South Africa. This research therefore contributes to the literature on financial literacy among university students- especially in the African context. Using the measure of financial knowledgeability (literacy) adopted for this study, surprisingly low levels of financial literacy exists among accounting students at the University of Venda, with only $38 \%$ of the participating students being financially literate. At the same time the study reveals that students who have taken money management course are more likely to be financially literate. These findings confirms the results of other studies conducted in South Africa that found similar results (Kotze and Smit, 2008; ECI Africa, 2004). This study therefore supports the call by the other studies for increased financial education and financial literacy in South Africa including curriculum reviews in universities to include money management modules/courses.

The study also found statistically significant gender differences in financial literacy with male Accounting students more likely to be more knowledgeable about financial matters than their female counterparts. This result affirms a 2002 study by Haiyang and Volpe on financial literacy among college students in the USA that found that women generally have less knowledgeable about personal finance than their men colleagues. With more and more women joining the workforce in South Africa, this finding points to the need to address the issue of inadequate knowledge about personal finance among women. Higher levels of financial literacy were found among the subgroup of students who financed their university education through bank loans compared to the groups that financed their studies through financial support by family or bursary. As this group of students depends on bank loans to take care of their financial needs, they need to be knowledgeable on personal finance issues such as the need to maintain good credit payment record as well as the habit of saving. Lower levels of financial literacy were found among subgroup of students whose monthly pocket incomes is R500 or less compared to their counterparts with larger monthly incomes. In addition to this result, the study also found that the views on planning and developing a savings plan between students who are more financially literate and those who are not, is not statistically different, implying that more financially knowledgeable students are not likely to implement a savings plan than in the same way as their less knowledgeable colleagues.

With about $70 \%$ of the participating students in this study, most probably coming from low income households, with monthly incomes of R500 or less, most of which is likely to be used for consumption purposes, the need to know about personal finance issues such investment or savings will not be a priority among students irrespective of their financial literacy level. Parents' socioeconomic status such as education levels or family incomes; as well the age and nationality of the students were found not to have any relationship with his/her level of financial literacy. Overall, this pilot study reveals that Bachelor of Commerce(Accounting) students at the University of Venda are not as financially literate as expected, confirming the findings of similar studies conducted on South African university students (Kotzè and Smidt, 2008). There is therefore the necessity to review the academic curriculum in the Bachelor of Commerce programme to include money management course. In evaluating how student financial knowledge correlates with their attitude and behaviour towards personal finance issues our analysis suggests that attitudes towards financial record keeping and savings do not seem to differ significantly between financially literate students and the less literate ones. The study also found that students who participated in family financial decisions and those who have taken money management course are more likely to be financially literate. Financially literate students were found to be more astute in their spending since they know the implications of doing otherwise. 


\section{References}

Bodvarsson, O. B. \& Walker, R. L. (2004). Do parental cash transfers weaken performance in college? Economics of Education Review, 23(5), 483-495.

Chang, R. Y. \& Hanna, S. (1992). Consumer Credit Search Behaviour. Journal of Consumer Studies and Home Economics, 16(1), 207-227.

Chen, H. \& Volpe, R. P. (1998). An analysis of personal financial literacy among college students. Financial Services Review, 7, 107-28.

Cleek, M. G. \& Pearson, T. A. (1985). Perceived causes of divorce: an analysis of interrelationships. Journal of Marriage and the Family, 47(1), 179-83.

FinMark Trust. (2004). Financial Literacy Scoping Study \& Strategy Project. Final Report 2004.

Godfrey, N. S. (2006). Making Our Students Smart about Money. Education Digest, 71(7), 21-26

Hilgert, M. A., Hogarth, J. M. \& Beverly, S. G. (2003). Household financial management: The connection between knowledge and behavior. Federal Reserve Bulletin, 89(7), 309-322.

Jorgensen, B. (2007). Financial Literacy of College Students: Parental and Peer Influences (Master's thesis). Retrieved from http://scholar.lib.vt.edu/theses/available/etd-10162007143627/unrestricted/Thesis_BJ2.pdf

Kinnunen, U. \& Pulkkinen, L. (1998). Linking economic stress to marital quality among Finnish marital couples. Journal of Family Issues, 19(6), 705-24.

Kinsey, J. \& McAlister, R. (1981). Consumer Knowledge of the Costs of Open-End Credit. Journal of Consumer Research, 15(2), 249-270.

Knight, F. H. (1971). Risk, uncertainty and profit, in: G. J. Stigler (Ed.), Chicago: University of Chicago Press, 1971.

Kotzè, L. \& Smidt, A. (2008). Personal finances: What is the possible impact on entrepreneurial activity in South Africa? Southern African Business Review, 12(3), 156-172.

Lyons, A. (2004). A profile of financially at-risk college students. Journal of Consumer Affairs, 38(1), 56-80.

Lyons, A. C. (2003). Credit practices and financial education needs of Midwest college students. Champaign, IL: Department of Agricultural and Consumer Economics, University of Illinois at Urbana-Champaign.

Lusardi, A. \& Mitchell, O. (2006). Financial literacy and planning: Implications for retirement wellbeing, Pension Research Council Working Paper 1, The Wharton School.

Lusardi, A. \& Mitchell, O. S. (2007). Financial Literacy and Retirement Preparedness: Evidence and Implications for Financial Education. Business Economics, 1, 35-44.

Njuguna, A. G. (2011). Predictors of Pension Finance Literacy: A Survey of Members of Occupational Pension Schemes in Kenya. International Journal of Business Management, 6(9), 101-112.

Perry, V. G. \& Morris, M. D. (2005). Who is in control? The role of self-perception, knowledge, and income in explaining consumer financial behavior. Journal of Consumer Affairs, 39(2), 299-313.

Roberts, B., Struwig, J., Gordon, S., Viljoen, J. \& Wentzel, M. (2012). Financial Literacy in South Africa: Results of a baseline national survey. Report prepared by the Human Sciences Research Council on behalf of the Financial Services Board. Pretoria: Financial Services Board.

South Africa Savings Institute. (2010). http://www.savingsinstitute.co.za/vsc_overview.htm. Accessed 15 February, 2014.

Stango, V. \& Zinman, J. (2007). Fuzzy math and red ink: When the opportunity cost of consumption is not what it seems, Working Paper, Dartmouth College.

Van Nieuwenhuyzen, B. J. (2009). Financial literacy as core competency of South African military officers: a measurement instrument. Unpublished PhD Thesis. Department of Public and Development Management, Stellenbosch University, South Africa.

Wolcott, I. \& Hughes, J. (1999). Towards understanding the reasons for divorce, Working Paper No. 20, Australian Institute of Family Services, Melbourne. 